\title{
Direct measurement of glacier thinning on the southern Tibetan Plateau (Gurenhekou, Kangwure and Naimona'Nyi glaciers)
}

\author{
TIAN Lide, ${ }^{1,2}$ ZONG Jibiao, ${ }^{1}$ YAO Tandong, ${ }^{1,2}$ MA Linglong, ${ }^{3}$ PU Jianchen, ${ }^{2}$ \\ ZHU Dayun ${ }^{4}$ \\ ${ }^{1}$ Key Laboratory of Tibetan Environmental Change and Land Surface Processes, Institute of Tibetan Plateau Research, \\ Chinese Academy of Sciences, Beijing, China \\ E-mail: Idt@itpcas.ac.cn \\ ${ }^{2}$ State Key Laboratory of Cryosphere, Cold and Arid Regions Environmental and Engineering Research Institute, \\ Chinese Academy of Sciences, Lanzhou, China \\ ${ }^{3}$ University of Chinese Academy of Sciences, Beijing, China \\ ${ }^{4}$ School of Geographical Sciences, Southwest University, Chongqing, China
}

\begin{abstract}
Numerous studies have confirmed the rapid retreat of Tibetan Plateau glaciers in recent decades, and resulting reductions in glacier volume. However, high-resolution determinations of the changes in glacier thickness remain sparse. This paper presents results based on differential GPS measurements to accurately measure glacier thickness change over the past few years. Measurements from the lower part of Gurenhekou glacier show an average thickness change of $-3.82 \mathrm{~m}$ over a 4 year period. On the lower part of Kangwure glacier we measured an average thickness change of $\mathbf{- 2 . 7 0 \mathrm { m }}$ over 3 years. On the upper part of Naimona'Nyi glacier (northern branch), western Himalaya, thickness changed by $-1.34 \mathrm{~m}$ on average between 2008 and 2010, and $-0.87 \mathrm{~m}$ between 2010 and 2013. Large temporal changes in thinning rates were found on Naimona'Nyi glacier, due to variations in local precipitation. Our measurements also show variable changes in glacier thickness over different parts of each glacier, with little dependence on elevation. The limited data also show glacier thinning in the accumulation zone.
\end{abstract}

KEYWORDS: climate change, glacier fluctuations, ice and climate, surface melt

\section{INTRODUCTION}

Glaciers provide distinctive indicators of global climate change. Measurements of ice loss in the high Himalaya and the Tibetan Plateau also provide important information because of the impacts on available water supplies and sealevel rise (Solomon and others, 2007; WGMS, 2008; Immerzeel and others, 2010; Kaser and others, 2010; Fujita and Nuimura, 2011; Scherler and others, 2011; Jacob and others, 2012).

A variety of methods have been employed to quantify changes in total glacier area during past decades in the Tibetan Plateau and Himalayan region, including in situ observations of glacier edge position (Ren and others, 2006), glacier mass balance, change in equilibrium-line altitude (ELA) (Fujita and Nuimura, 2011; Yao and others, 2012) and glacier area changes detected by satellite-based remote sensing and airborne images (Braithwaite, 2002; Kargel and others, 2005; Ren and others, 2006; Ye and others, 2006; Andreassen and others, 2008; Bolch and others, 2010a,b; Narama and others, 2010; Bhambri and others, 2011). Results show that most of the glaciers in central Asia are undergoing rapid retreat and ice loss (Dyurgerov and Meier, 2000; Peduzzi and others, 2010; Bolch and others, 2012; Yao and others, 2012). The Karakoram glaciers provide an exception, where glacier advances and slight mass gains have been detected (Scherler and others, 2011; Gardelle and others, 2012). Yao and others (2012) have ascribed this different response to increased precipitation in recent years. Analyses of earlier mass-balance observations of a large number of glaciers in the Himalayan region indicate the glaciers have undergone intensive shrinkage, with less shrinkage to the north on the Tibetan Plateau (Yao and others, 2012).

Accelerating glacier melt has directly impacted lake water levels (Ye and others, 2007) and river water resources (Zhang and others, 2012). However, quantitative estimations of the contribution of glacier meltwater depend on knowledge of changes in glacier ice volume, compared with glacier area change (Scherler and others, 2011).

Several methods have been used to derive such estimates, including digital elevation models (DEMs) from available topographic maps and multitemporal satellite images, and stake-based in situ mass-balance observations (Yao and others, 2012). Other feasible approaches used to estimate glacier surface change include comparison of precise differential GPS (dGPS) measurements (Shangguan and others, 2010; Zhang and others, 2012), using Shuttle Radar Topography Mission (SRTM) data (Surazakov and Aizen, 2006), DEMs derived from satellite and topographic data and combinations of various data sources (Nuimura and others, 2012). The uncertainty in the above studies is usually measured in meters when estimating the glacier thickness change. Disagreement between different studies can be quite large, even for the same glacier regions, indicating the low reliability of the estimates, especially for short time periods (Bolch and others, 2011; Nuimura and others, 2012). However, high-precision data, within decimeter accuracy, on changes in glacier thickness remain sparse for the alpine glaciers on the Tibetan Plateau, where access is difficult.

This paper presents a different approach for measuring glacier thickness changes on the southern Tibetan Plateau, in an attempt to provide accurate data on changes over 


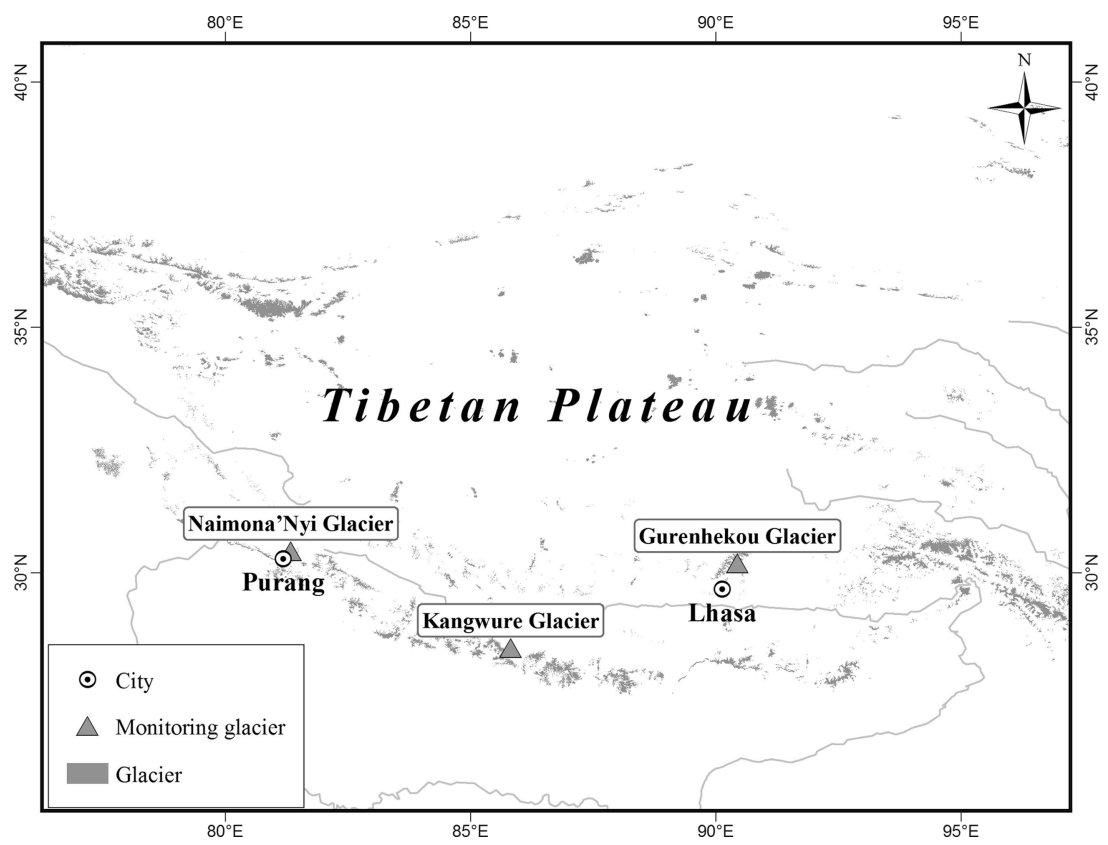

Fig. 1. Locations of the glaciers monitored on the southern Tibetan Plateau.

recent years. Glacier surface positions were monitored using dGPS repeatedly on three glaciers, to derive change in glacier thickness with $\mathrm{cm}$ precision. This ignores possible bedrock isostatic rebound, which is unlikely to be significant during our time span of interest. Although our studies have been limited to a small number of glaciers, and do not cover any entire glacier, we find rapid changes in glacier thickness in different areas. We believe that our results will be useful for comparing changes in glacier thickness as estimated from satellite and topographic map data.

\section{METHODS AND DATA}

To measure glacier surface elevation change in the field, our field team performed real-time kinematic (RTK) GPS measurements using a pair of E650 type dGPS units manufactured by Unistrong Company. Exact geographic positions on the glacier surface were reoccupied repeatedly to determine any elevation change. Our procedure first installed a base station GPS receiver on a large boulder close to each glacier or on a hilltop. The position of this station was marked by imbedding a steel bolt on the boulder. Another GPS rover receiver was used to measure point positions on the glacier surface. The two dGPS units were connected by radio signal, enabling an RTK survey to be carried out with cm-level accuracy. These points were remeasured using the same configuration and the same base station after intervals of years. We then compared the relative elevation differences for each point in the two measurements. The elevation change during the two measurements reflects any change in glacier thickness.

Two errors can occur with this approach: one from the dGPS itself and another from the measurement procedure. For the dGPS, the horizontal precision is $( \pm 1 \mathrm{~cm} \pm 1 \mathrm{ppm}) D$ and the vertical precision is $( \pm 2 \mathrm{~cm} \pm 1 \mathrm{ppm}) D$, where $D$ is the distance between the two GPS receivers. Because our practice keeps the distance between the base and roving GPS receivers less than $10 \mathrm{~km}$, the estimated error is within $\pm 2 \mathrm{~cm}$ horizontally and $\pm 3 \mathrm{~cm}$ vertically. The measurement method can also introduce errors. In practice, a tolerance of $30 \mathrm{~cm}$ in horizontal distance is allowed for the later dGPS measurement in searching for the previous measured sites. This method also introduces a minor error in elevation if the glacier surface is not horizontal. The amount of error depends on the slope of the glacier surface. However, our measured glacier points have been chosen where the surface is quite flat, yielding an estimated maximum error of $\pm 2 \mathrm{~cm}$. Therefore, the maximum measured error in elevation change should be less than $\pm 5 \mathrm{~cm}$.

Snow thickness on the glacier surface was not measured during our surveys. Annual changes in snow thickness may increase the uncertainty. However, there was usually no deep snow on the glacier surfaces during our measurements, and the effect of snow depth change is ignored in this work.

Ground-penetrating radar (GPR) had previously been used to track glacier thickness, internal structure and other snow ice properties (Watts and England, 1976; Arcone and others, 1995; Moore and others, 1999; Pälli and others, 2002). In our study, glacier depths were measured using GPR in order to give a general idea of the glacier thickness and the bed topography underlying the glacier. Our GPR measurements were performed with a pulseEKKO PRO system from Canadian Sensors \& Software, Inc. We used $100 \mathrm{MHz}$ frequency antennas, with a $4 \mathrm{~m}$ separation between the two antennas. Routes along the central and transverse lines of each glacier were measured. We mapped the surface topography and bed topography along the measured profiles using measured thickness data and glacier surface GPS data.

\section{MEASUREMENT RESULTS}

Figure 1 shows the locations of the three study glaciers on the southern Tibetan Plateau, and Table 1 lists the dGPS measurement information from the three glaciers. Because of harsh conditions and weather, measurements were not made on all of the glaciers each year. We measured the Gurenhekou glacier sites twice within a 4 year period. On 

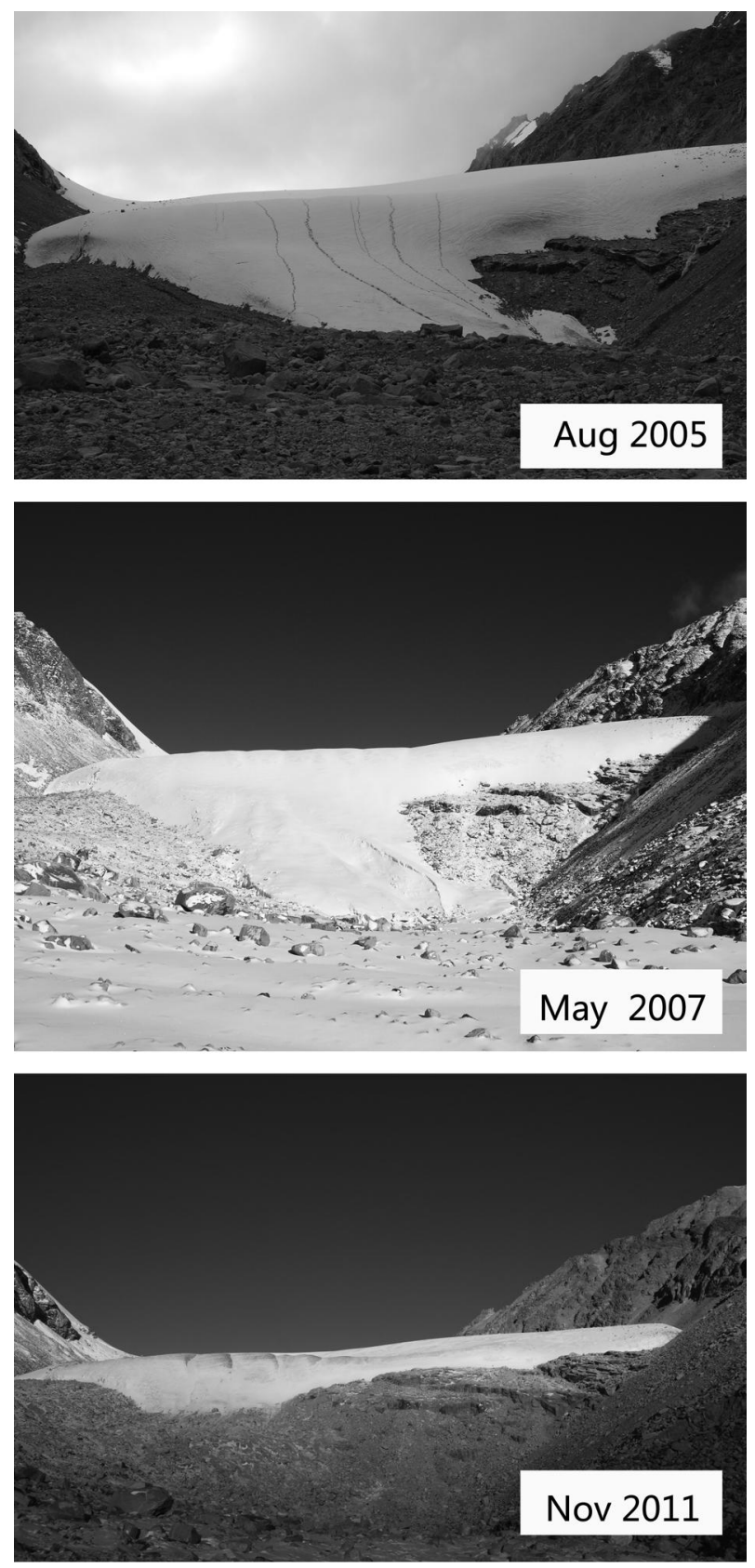

Fig. 2. Photographs of the Gurenhekou glacier terminus from 2005 to 2011, showing its rapid retreat, with the glacier tongue melting back from the valley in only a few years.

Kangwure glacier, we made measurements three times in 3 years, and on Naimona'Nyi glacier three times in 5 years. Technically, the dGPS measurement requires a smooth glacier surface, and is also limited by the radio signal reception between the two dGPS receivers. Consequently, we made the observations on the lower parts of Kangwure and Gurenhekou glaciers, and the upper part of Naimona'Nyi glacier. The specific dGPS and GPR measurement sites on each glacier are shown in Figures 4, 6 and 9.

\subsection{Gurenhekou glacier}

Gurenhekou valley glacier lies near the town of Yangbajing, on the southern slope of the Nyainqentanglha mountains. (Fig. 4, further below). Flowing to the southeast, the glacier extends $\sim 2.9 \mathrm{~km}$ and covers an area of $\sim 1.28 \mathrm{~km}^{2}$. It lies between 5450 and $5900 \mathrm{~m}$ elevation. Ma and others (2008)
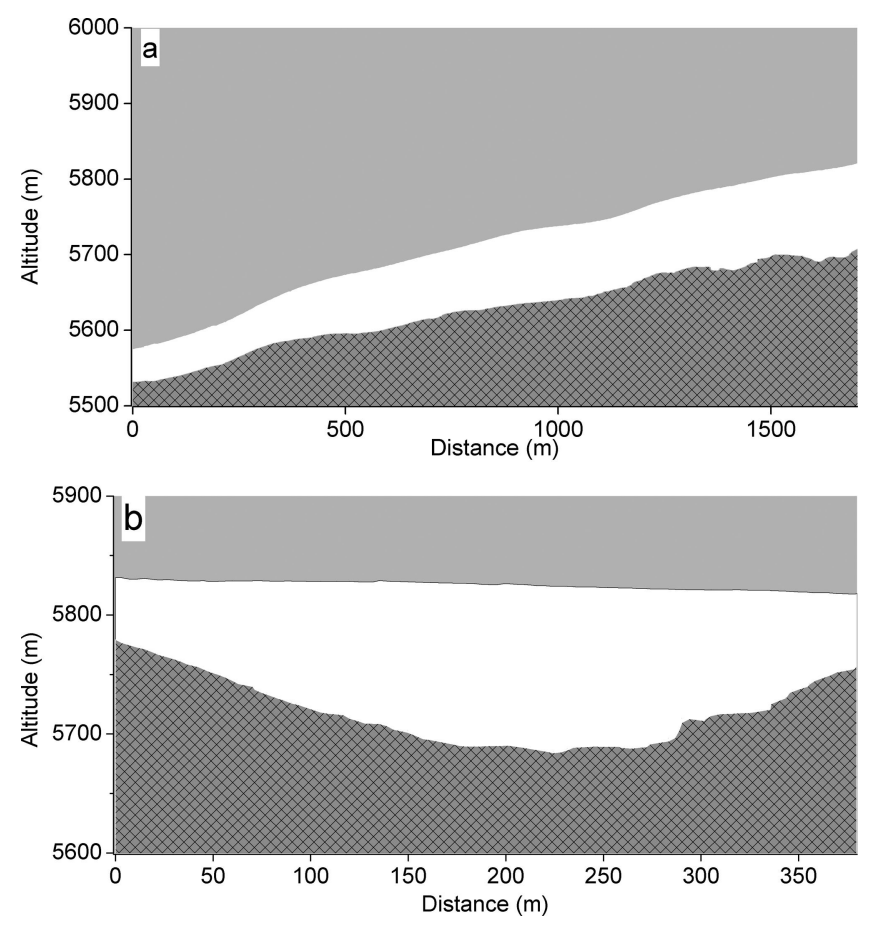

Fig. 3. Gurenhekou glacier thickness results measured by GPR: (a) flowline profile from the bottom of the glacier to its upper reaches; (b) transverse profile.

have estimated the volume of glacier ice to be $\sim 0.045 \mathrm{~km}^{3}$, based on GPR measurements. Yu and others (2013), using mass-balance stake measurements, estimated the annual ELA to be 5640-5840 m during the 2004-08 period.

The terminus of Gurenhekou glacier is in rapid retreat. A geodetic study showed that the glacier retreated at a rate of $8.3 \mathrm{~m} \mathrm{a}^{-1}$ from 1970 to 2004 and $13.25 \mathrm{~m} \mathrm{a}^{-1}$ from 2004 to 2006 (Pu and others, 2006). Figure 2 shows photographs of the retreat of this glacier as the glacier tongue disappeared from the valley in only a few years. Ma and others (2008) calculate that the glacier area has shrunk from $1.50 \mathrm{~km}^{2}$ in 1970 to $\sim 1.28 \mathrm{~km}^{2}$ in 2007 , a decrease of almost $15 \%$.

Ice depths of the glacier were measured using GPR in 2005, 2008 and 2009 along one centre-line profile and one transverse profile. Surface and bottom elevations of the glacier were calibrated by synchronous GPS measurements. Figure 3 presents the results measured along the two profiles. Figure 3 a shows the flowline profile from the terminus to the upper reaches of the glacier. Figure $3 b$ presents the transverse profile. The glacier surface remains rather gentle, with a general slope of $\sim 8^{\circ}$ (Fig. 3a).

The glacier surface positions were first measured by dGPS in May 2007. In November 2011, some of the points on the

Table 1. Differential GPS measurement dates and numbers of data points for the three glaciers on the southern Tibetan Plateau

\begin{tabular}{lcccc}
\hline Glacier & First date & Second date Third date $\begin{array}{c}\text { Number of } \\
\text { points measured }\end{array}$ \\
\hline $\begin{array}{l}\text { Gurenhekou } \\
\text { Kangwure }\end{array}$ & May 2007 & Nov 2011 & - & 48 \\
$\begin{array}{l}\text { Naimona'Nyi } \\
\text { (northern branch) }\end{array}$ & Sep 2007 & Nov 2009 & Aug 2010 & 20 \\
& & Oct 2010 & Sep 2013 & 132 \\
\hline
\end{tabular}




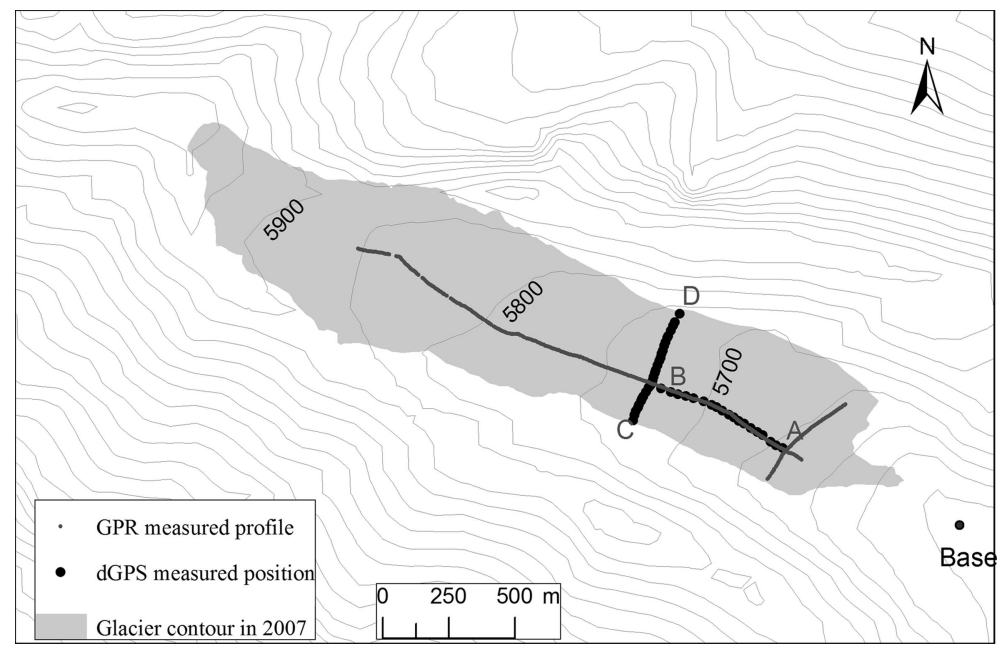

Fig. 4. Repeat measurement points on Gurenhekou glacier from 2007 to 2011. Large dots indicate the dGPS measurement locations. The measurement profiles are shown by $A B$ along the flowline profile and $C D$ along the transverse profile. The thin dot line shows the GPR measurement profile.

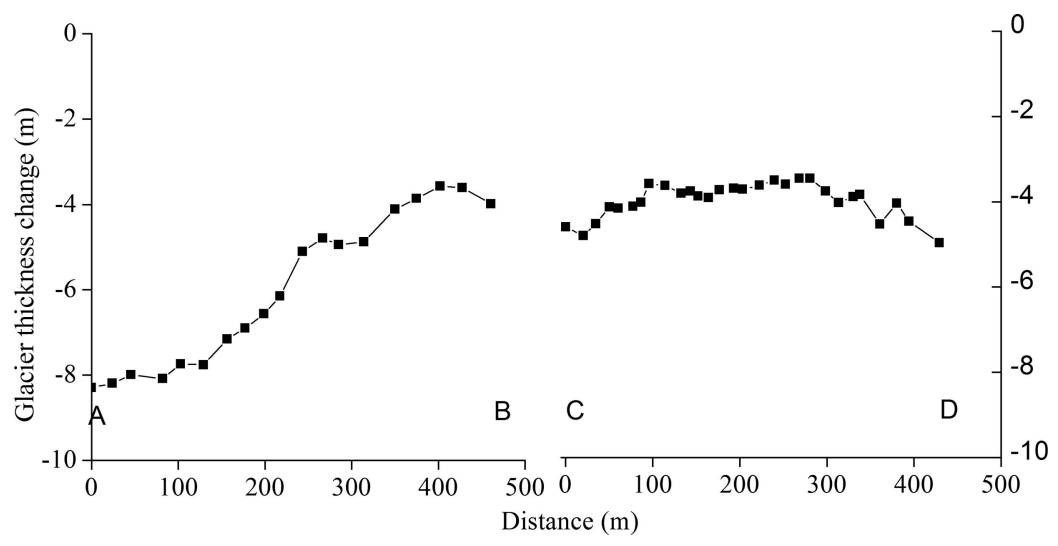

Fig. 5. Measurements on Gurenhekou glacier from 2007 to 2011. Dots between A and B show thickness changes for the flowline profile from the terminus of the glacier upwards. Dots between $\mathrm{C}$ and $\mathrm{D}$ show thickness changes along the transverse profile shown in Figure 4.

glacier were remeasured. Due to radio signal connection problems, we only measured positions on the lower part of the glacier. Figure 4 shows the positions of the 48 remeasured glacier points.

Measurements along the two profiles show that glacier surface elevations decreased from $>8 \mathrm{~m}$ near the glacier terminus and by $\sim 4 \mathrm{~m}$ along the transverse measurement during the period May 2007 to November 2011. Figure 5 illustrates the changes in glacier thickness at the measurement points in the lower part of the glacier. The rapid retreat of the glacier terminus resulted in large changes in glacier thickness, a reduction of $>8 \mathrm{~m}$ at the glacier terminus. The transverse profile shows relatively constant changes in glacier thickness. Slightly faster glacier thinning was also found at the two ends of the transverse profile. If we remove the high values near the glacier terminus and edges, a more representative average glacier thickness change might be $-3.82 \mathrm{~m}$, or a rate of $-0.85 \mathrm{~m} \mathrm{a}^{-1}$ in the flat lower portions of the glacier.

The two measurements were not performed in the same season. In November 2011 after the melting season, only thin snow or bare ice covered the measured part of the glacier, but there was snow cover in May 2007. This difference may yield an underestimated glacier thickness change as given in Table 2. However, the surface snow thickness change is much less than the measured glacier thickness change of $\sim 4 \mathrm{~m}$.

Table 2. Calculated average glacier thinning rates for the three glaciers based on dGPS measurements.

\begin{tabular}{|c|c|c|c|c|c|c|}
\hline \multirow[t]{2}{*}{ Glacier } & \multirow{2}{*}{$\begin{array}{l}\text { Length } \\
\text { km }\end{array}$} & \multirow{2}{*}{$\begin{array}{l}\text { Area } \\
\mathrm{km}^{2}\end{array}$} & \multirow[t]{2}{*}{ Observation period } & \multirow{2}{*}{$\begin{array}{c}\text { Glacier thickness change } \\
\mathrm{m}\end{array}$} & \multicolumn{2}{|c|}{ Thickness change rate } \\
\hline & & & & & $\mathrm{ma}^{-1}$ & m w.e. $a^{-1}$ \\
\hline Gurenhekou & 2.9 & 1.28 & May 2007-Nov 2011 & -3.82 & -0.85 & -0.72 \\
\hline Kangwure & 3.2 & 1.96 & Sep 2007-Nov 2009 & -2.70 & -0.85 & -0.72 \\
\hline Naimona'Nyi (northern branch) & 11 & 14.6 & Sep 2008-Sep 2013 & -2.21 & -0.42 & -0.36 \\
\hline
\end{tabular}




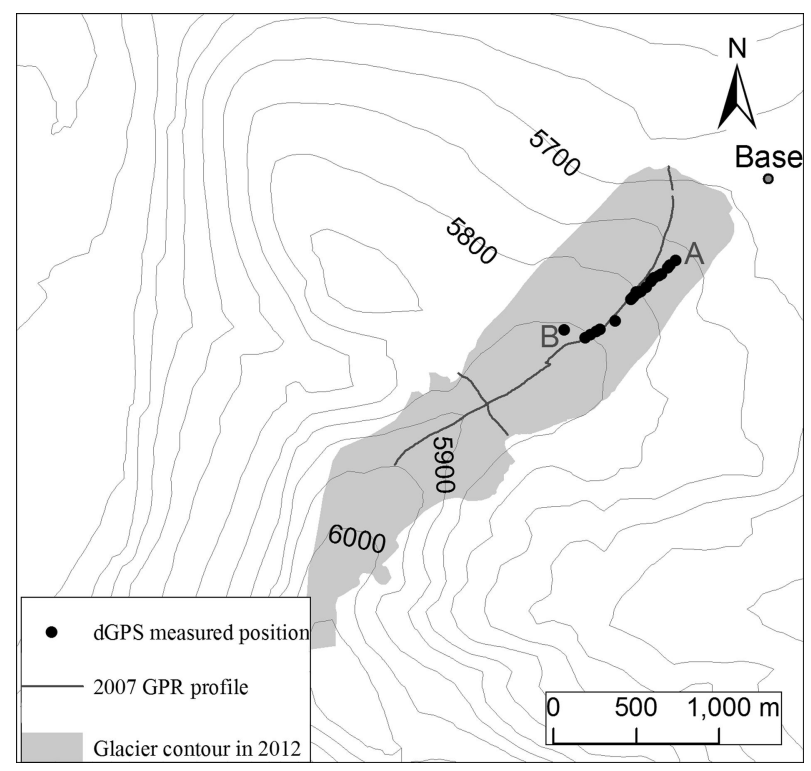

Fig. 6. Kangwure glacier GPS and GPR measurements. Large dots from A to B show the position of dGPS measurements. Thin dot lines indicate the flowlines and transverse GPR profile.

\subsection{Kangwure glacier}

Kangwure glacier lies on the northern side of Xixiabangma peak, in the central Himalaya. In 2008, it had an area of $\sim 1.96 \mathrm{~km}^{2}$ and a length of $\sim 3.2 \mathrm{~km}$ (Ma and others, 2010) (Fig. 6). It flows northeastward, with gentle slopes near the terminus and the northwest edge, but with a cliff along the southeast edge. It had once been connected to other glaciers near the summit, but is now almost totally isolated due to melting. A study based on satellite imagery, topographic maps and GPR measurements shows that it lost $\sim 34 \%$ of its area between the 1970s and 2008, and almost half of its ice volume (Ma and others, 2010).

We measured the glacier thickness changes three times: in September 2007, November 2009 and August 2010. The glacier thickness was also measured by GPR in 2007 along different profiles. Figure 6 shows all the measured points.

Figure 7 shows the glacier thicknesses measured by GPR, showing a transverse profile near the middle of the glacier, together with a profile along the main flowline (position shown in Fig. 6). We note a relatively flat bottom of the glacier (Fig. 7a), implying that this glacier was not formed in a valley nor did it exist long enough form a significant valley of its own. Such a glacier may be more vulnerable to climate warming. The surface sawtooth shape in Figure $7 \mathrm{~b}$ results from the measurement gaps and uncertainty in portable GPS measurements at the beginning of our GPR surveying.

Figure 8 shows the dGPS results from the lower part of the glacier. From November 2009 to August 2010, the glacier thickness changes varied from $-0.39 \mathrm{~m}$ to $-0.86 \mathrm{~m}$, with an average of $-0.57 \mathrm{~m}$. This 9 month period of glacier thickness change yields an annual glacier thickness change rate of $-0.76 \mathrm{~m} \mathrm{a}^{-1}$. From September 2007 to August 2010, the changes in glacier thickness varied from -2.28 to $-3.12 \mathrm{~m}$ at the eight points. The average thickness loss at our measuring points was $2.70 \mathrm{~m}$ over the 3 year period, with an average annual glacier thickness change rate of $-0.85 \mathrm{~m} \mathrm{a}^{-1}$.

The relatively large variations of the changes in glacier thickness at different sites appear to relate to the glacier surface roughness of $\sim 1 \mathrm{~m}$. The microtopography on the
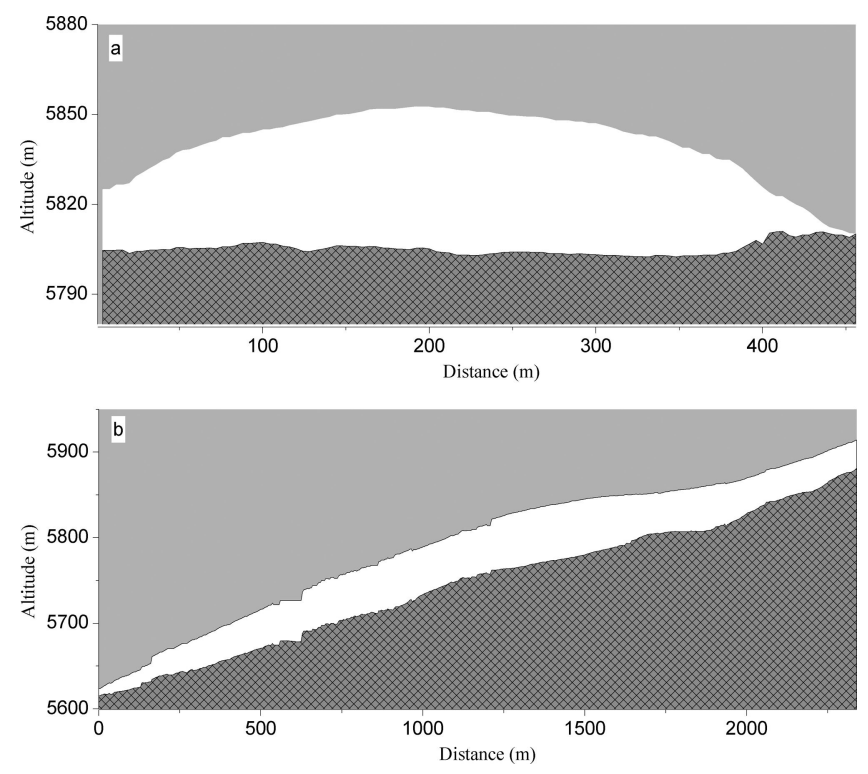

Fig. 7. Glacier thicknesses measured by GPR and GPS on Kangwure glacier in September 2007 for (a) the middle transverse profile and (b) the flowline profile.

glacier surface moves with the glacier flow, while our measured point remains at an exact geographical location (latitude and longitude). This can yield a spatial fluctuation in the changes in glacier thickness (Fig. 8). This effect is minimized with longer observation intervals, especially for estimates of the rate of glacier thickness change.

\subsection{Naimona'Nyi glacier}

With a length of $>11 \mathrm{~km}$ and a maximum width of $>2.5 \mathrm{~km}$, Naimona'Nyi glacier is one of the largest glaciers surrounding Naimona'Nyi peak (7694 m a.s.I.). It lies in a wide valley with a smooth surface on the upper part, but a rough surface at the lower part due to surface melting. One branch of the glacier flows northward, providing meltwater for the upper branch of the Kongque river, an upper tributary of the Ganges. The other branch flows southeastward, providing meltwater to lake Manasarovar, Tibet's holiest lake. Remotesensing studies have shown that glaciers in this area are

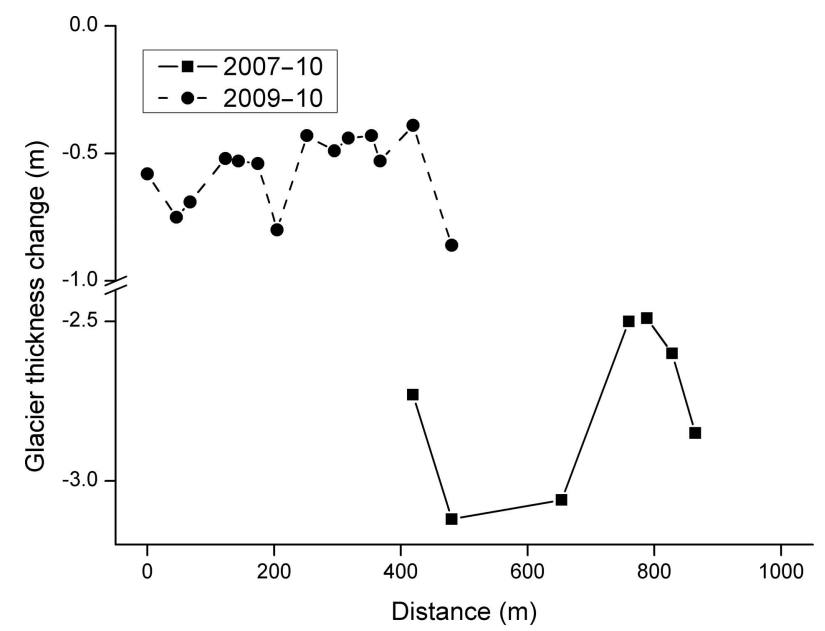

Fig. 8. Glacier thickness changes on Kangwure glacier measured between 2007 and 2010. The positions of the measurements are shown as A and B in Figure 6. 

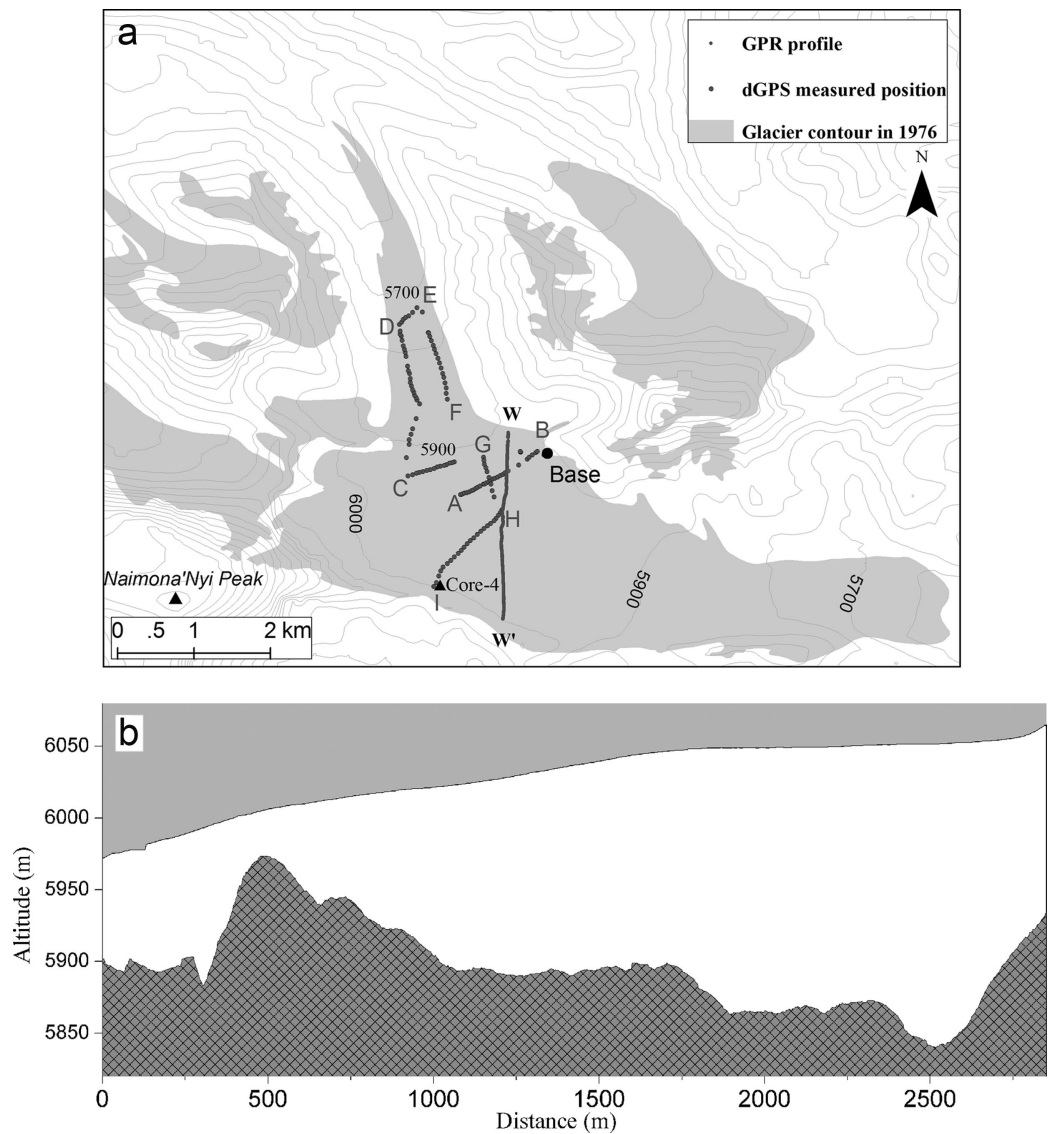

Fig. 9. (a) Naimona'Nyi glacier. Black dots show dGPS measurements, marked by letters $A-I$. Line $W-W^{\prime}$ indicates the GPR profile measured in 2008. (b) A GPR measured profile across the glacier. Surface elevations were calibrated by simultaneous dGPS measurements.

shrinking with climate warming. From 1976 to 2003, the glaciated area decreased from $84 \mathrm{~km}^{2}$ to $77 \mathrm{~km}^{2}$ (Ye and others, 2006).

Figure 9 shows the dGPS measurement sites on the upper reaches of the glacier, as well as one GPR glacier depth profile. The GPR measurements show that the topography underlying the glacier undulates. Deep ice lies beneath the side near the peak, while shallow ice lies under the northeast side. Elevation changes of the glacier surface imply that the dominant accumulation zone lies on the south edge of the glacier, near the divide.

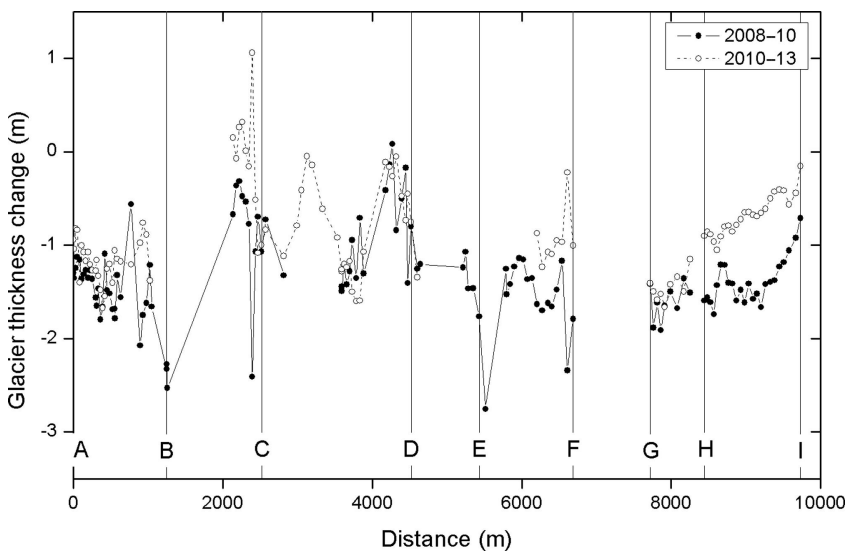

Fig. 10. Naimona'Nyi glacier thickness changes during 2008-13. Letters A-I indicate the positions of the measured points on the glacier, as shown in Figure 9.
Our dGPS measurements were taken on the northern branch of the glacier. They were limited to the upper part of the glacier because of difficult terrain in the lower part. The glacier surface generally varies little, except for the sharp incline near the peak. The gradual change of surface elevation results from ice flows from several different accumulation zones, and the existence of a superglacial river. Figure 10 shows the measured changes in glacier thickness from 132 points acquired during two periods, 2008-10 and 2008-13. The spatial constancy of glacier thickness change during the two intervals indicates that some parts of the glacier lost ice rapidly, some more slowly, while some even gained ice. This inhomogeneous glacier thinning relates to different ice flows within the glacier. However, on average, the glacier thinning is significant. During the interval 2008-10, the average glacier thickness over our measuring points changed by $-1.34 \mathrm{~m}\left(-0.67 \mathrm{~m} \mathrm{a}^{-1}\right)$. We found a lesser average change of $-0.87 \mathrm{~m}\left(-0.29 \mathrm{ma}^{-1}\right)$ between 2010 and 2013. The average thinning rate was $0.42 \mathrm{~m} \mathrm{a}^{-1}$ over the entire 5 year period 2008-13. At a few sites, some of the larger glacier thickness changes measured between 2008 and 2010 rebounded during the following year. This occurred when the glacier microtopography changed sharply over a short distance (e.g. near the superglacial river). However, the 5 year average smooths this effect. In profile HI (Fig. 9), the thinning rate shows a dramatically decreasing trend with increasing elevation, up to $6073 \mathrm{~m}$ at the highest point. Since the highest point at I is near the glacier flow divide, we assume this point lies within the glacier's accumulation zone. A shallow ice core drilled at our nearest measurement site in 2010 (Fig. 9a) showed that 
this part of the glacier holds recent ice, from the past few years (Tian and others, 2012), indicating that it lies in the glacier's accumulation zone. The loss of thickness measured at the top of the glacier indicates that the accumulation zone is also losing thickness.

\section{DISCUSSION}

The observed changes in glacier thickness over the past few years provide a basis for evaluating the relationship between changes in glacier thickness and the warming climate, and its potential impact on the hydrology cycle. These observations are based on dGPS observations on the lower portions of two glaciers and upper portion of one additional glacier. Although the observations did not cover the entire glacier surface, the high-precision results provide valuable data on how rapidly glaciers have lost their ice and how the glacier thicknesses change temporally and spatially in the southern Tibetan Plateau. Table 2 summarizes the measured results of glacier thickness changes.

Table 2 shows that all three monitored glaciers exhibited rapid thinning over the past few years, at rates between 0.42 and $0.84 \mathrm{~m} \mathrm{a}^{-1}$. Next, we discuss the rates of temporal thickness change for each specific glacier. On two of the glaciers, we have two observation intervals. For Kangwure glacier, the derived glacier thinning rate of $0.85 \mathrm{~m} \mathrm{a}^{-1}$ between 2007 and 2010 falls close to the rate of $0.76 \mathrm{~m} \mathrm{a}^{-1}$ between 2009 and 2010. However, the thinning rates for Naimona'Nyi glacier appear to change significantly between these periods. Our measurements show a much weaker average thinning $\left(0.29 \mathrm{~m} \mathrm{a}^{-1}\right)$ between 2010 and 2013, compared with $0.67 \mathrm{~m} \mathrm{a}^{-1}$ during the interval 2008-10. Meteorological data from Purang $\left(30.29^{\circ} \mathrm{N}, 81.176^{\circ} \mathrm{E}\right.$; 3880 ma.s.l.) show that average annual precipitation increased from $178 \mathrm{~mm} \mathrm{a}^{-1}$ in the first 2 years to $272 \mathrm{~mm} \mathrm{a}^{-1}$ in the later 3 years of our observations, an increase of $>50 \%$. The precipitation amount in the first 9 months of 2013 reached $388 \mathrm{~mm}$ at Purang $(20 \mathrm{~km}$ from Naimona'Nyi glacier), much higher than the annual average precipitation of $153 \mathrm{~mm}$. The large precipitation gain on the glacier surface and a slight air temperature decrease from $4.3^{\circ} \mathrm{C}$ to $3.9^{\circ} \mathrm{C}$ may qualitatively explain the lower thinning rate in the past 3 years on Naimona'Nyi glacier.

The observed glacier thickness change rates vary spatially. The dGPS measurements cover only a limited area, all within the ablation zones on Kangwure and Gurenhekou glaciers. Most likely, the thinning in the lower portions of the glaciers results largely from surface melting due to increasing air temperatures. Unfortunately, thinning data are not available on the upper portions of the glaciers. However, other evidence shows that even the upper part of Kangwure glacier is losing ice. Comparing the glacier outline from the 1974 topography map with current satellite images shows that what was previously part of one large glacier has now become isolated, with considerable shrinkage of the glacier edge near the summit ( $\mathrm{Ma}$ and others, 2010). On Naimona'Nyi glacier, the rate of change in the measured glacier thickness shows large variations between different sites (Fig. 10). We also observed similar spatial patterns of thickness change during these two periods. The varying thinning rates appear to relate to the ice flows having formed within different accumulation zones. The non-uniform thinning of the glacier surface reminds us to be cautious of using the ICESat (Ice, Cloud, and land Elevation Satellite) data from different years to estimate glacier thickness changes over multiple years. Although we observe a slight decrease in the thinning trend toward higher elevations, we note that even the uppermost site is experiencing glacier thinning. Glacier thinning measured in the accumulation zone may imply that the thinning is not entirely caused by surface melting. Changes in the flow of the underlying glacier may also be involved. Increasing glacier flow velocity can also cause glacier thinning. Unfortunately, no surface velocity data are yet available for this portion of the glacier.

Our results confirm earlier work on ice loss on the Tibetan Plateau. On Naimona'Nyi glacier, ice cores drilled in the middle of the glacier show that glacier accumulation over recent decades has been decreasing due to accelerating surface melting (Kehrwald and others, 2008). We also compared dGPS measures of glacier thinning with massbalance observations derived using ablation stakes on the three glaciers (Yao and others, 2012; Yu and others, 2013) over similar periods. However, the dGPS method and the surface mass balance by stakes method differ somewhat. The stake method only measures the glacier surface mass balance at a potentially moving site, while the dGPS method used here measures the glacier surface shape change at a fixed geographic location. Theoretically, for a stationary glacier with zero mass balance, the stake method will always show ice loss in the ablation zone, and snow gain in the accumulation zone. However, the dGPS method will find no change in both the ablation zone and accumulation zone of a glacier in equilibrium. Indeed, we did not find obvious correlations between glacier thickness change rate and glacier surface elevation except near the glacier terminus (Gurenhekou glacier) and at the uppermost site near the upper rock boundary (Naimona'Nyi glacier). Therefore, although our results are not based on the entire span of any glacier (two surveys involved only the lower portions of the glaciers, while one involved only the upper part of the glacier), we still believe the dGPS results can be compared with the mass balances acquired from the entire glaciers derived from stake measurements. For easy comparison, we converted the glacier thinning rate data to water equivalent using an ice density of $0.85 \mathrm{~g} \mathrm{~cm}^{-3}$ (Table 3). The observations cover roughly the same period between 2007 and 2011 for each specific glacier (except for Gurenheko glacier, where a 1 year gap exists between the two measurements). The glacier thickness changes conform with the dGPS method results, but the stake mass-balance results exhibit larger variations. Both methods show obvious ice loss on all three glaciers. However, the ice-thinning rates determined by dGPS appear higher than by conventional mass-balance measurements from stakes. Gurenhekou glacier exhibited the largest difference, with an annual ice change rate of $-720 \mathrm{~mm}$ w.e. $\mathrm{a}^{-1}$ determined by dGPS, as compared with a rate of $-163 \mathrm{~mm}$ w.e. $\mathrm{a}^{-1}$ determined by stakes. However, we cannot estimate how much of this difference results from ablation zone melting vs the difference in observation periods. The rate of ice loss determined by dGPS only slightly exceeds that determined by stakes on Kangwure glacier. On Naimona'Nyi glacier (only for the 2 years 200810 ), the dGPS measurements were limited to the upper portion of the glacier (except the cliff near the peak); the lower portion was not covered because of difficult surface conditions. Nevertheless, we also found a higher ice loss rate by dGPS than by stake measurements. The stake method only measures the glacier surface mass balance, while the dGPS 
Table 3. A comparison between dGPS measurements of glacier thickness change vs stake-based mass-balance changes

\begin{tabular}{|c|c|c|c|c|}
\hline \multirow[t]{2}{*}{ Glacier } & \multicolumn{2}{|c|}{ dGPS-measured glacier thinning } & \multicolumn{2}{|c|}{ Stake-based mass balance* } \\
\hline & Duration & $\begin{array}{l}\text { Mass loss rate } \\
\text { mm w.e. } \mathrm{a}^{-1}\end{array}$ & Duration & $\begin{array}{c}\text { Mass loss rate } \\
\text { mm w.e. } \mathrm{a}^{-1}\end{array}$ \\
\hline Gurenhekou & May 2007-Nov 2011 & 720 & 2007-10 & 163 \\
\hline Kangwure & Sep 2007-Aug 2010 & 720 & 2007-10 & 626 \\
\hline Naimona'Nyi (north branch) & Sep 2008-Oct 2010 & 570 & 2008-10 & 347 \\
\hline
\end{tabular}

*Sources: Yao and others (2012); Yu and others (2013).

measures changes in glacier thickness that include both the surface mass balance and underlying ice flow. Therefore, the comparison implies that the glacier surface ice loss cannot explain the total change in glacier thickness, and glacier flow may also play some role in glacier thinning.

Various techniques have been applied to determine glacier thinning rate from digital terrain models (DTMs) based on satellite images and other available data. Xiao Dongkemadi glacier, Tanggula mountains, experienced a mean rate of ice elevation decrease of $0.21 \mathrm{mw}$.e. $\mathrm{a}^{-1}$ from 1969 to 2007 (Shangguan and others, 2008). In the central Qilian mountains, the thinning rates of two glaciers were 0.40 and $0.33 \mathrm{~m} \mathrm{a}^{-1}$ between 1956 and 2007, respectively (Shangguan and others, 2010). In the eastern Qilian mountains, Shuiguan river No. 4 glacier thinned at a rate of $0.42 \mathrm{~m}$ w.e. $\mathrm{a}^{-1}$ in the ablation zone from 1972 to 2007 ( $\mathrm{Li}$ and others, 2010). The thinning rate between 1957 and 2007 for the glacier surface covered by RTK-GPS measurements reached $0.37 \pm 0.01 \mathrm{mw}$.e. $\mathrm{a}^{-1}$ (Zhang and others, 2012). A detailed study using DTMs from satellite images in the Everest area of the southern Himalaya, Nepal, shows a rate of $0.32 \pm 0.08 \mathrm{~m}$ w.e. $\mathrm{a}^{-1}$ for glacier mass loss between 1970 and 2007 (Bolch and others, 2011). The area-weighted average regional mass balance was calculated to be $-0.40 \pm 0.25 \mathrm{mw}$.e. $\mathrm{a}^{-1}$ in the Khumbu region of the Nepalese Himalaya (Nuimura and others, 2012). All these results show similar patterns of decreased glacier thickness. Our results show glacier thickness change rates ranging from -0.57 to $-0.72 \mathrm{~m}$ w.e. $\mathrm{a}^{-1}$ (Table 3 ), which are much higher than the results reported above. The much lower thinning reported from Naimona'Nyi glacier during the 2010-13 period probably results from extremely high local precipitation during that period. We cannot yet be sure whether previous work underestimated the glacier thinning rate or whether the rate of glacier thinning is accelerating. A longer period of monitoring glacier thickness changes by dGPS will be required to confidently compare them with earlier results based on other methods.

A number of studies show the diversity of glacier mass balance in different parts of the Tibetan Plateau (Fujita and Nuimura, 2011; Scherler and others, 2011). Yao and others (2012) suggest that this may result from different atmospheric circulation patterns affecting the southern and northern regions of the plateau, which might cause precipitation changes in a spatially recognizable pattern. Therefore, we feel it important to use dGPS methods to measure glacier thickness changes on more glaciers from different parts of the plateau. Methods also need to be found to confidently measure glacier thinning on the upper portions of glaciers.

To understand how a glacier lost its ice and how climate controls it, the comparison between glacier depth changes from dGPS measurements and simultaneous stake-measured glacier surface mass balance requires further study. Also, observation of glacier surface energy budgets can help understand the glacier surface ablation, as has been done on Parlung No. 4 glacier, southeast Tibetan Plateau (Yang and others, 2011). Thus, glacier meteorological observations are crucial to understanding the glacier melting processes, including glacier thinning.

\section{CONCLUSIONS}

We have presented direct measurements of glacier thinning by performing cm-level accuracy measurement using RTK dGPS surveys at three glaciers on the southern Tibetan Plateau (Gurenhekou, Kangwure and Naimona'Nyi glaciers). Measurements were carried out on the lower portions of the first two glaciers and on the upper reaches of the third. Survey results show significant thinning on all three glaciers over the past few years. Gurenhekou glacier lost $3.82 \mathrm{~m}$ of thickness over the period May 2007 to November 2011. Kangwure glacier, on Xixiabangma mountain, lost $2.70 \mathrm{~m}$ of thickness over 3 years, from September 2007 to August 2010. Naimona'Nyi glacier, one of the largest glaciers in the western Himalaya, lost $1.34 \mathrm{~m}$ of thickness in the 2 years 2008-10, and a further $0.87 \mathrm{~m}$ between measurements in 2010 and 2013. Annual thinning rates from the three glaciers vary from 0.42 to $0.87 \mathrm{~m} \mathrm{a}^{-1}$ (0.36 to $0.71 \mathrm{~m}$ w.e. $\mathrm{a}^{-1}$ ) during the observation periods.

This work shows that the rates of temporal glacier thickness change vary with local climate, and that changes in precipitation amount are an important factor in the changes we observe. We also found that changes in glacier thickness vary spatially over different parts of each glacier. This changing glacier thinning rate depends less on elevation than on different ice flow paths.

Our study observed losses in glacier thickness even in the accumulation zone of Naimona'Nyi glacier, and also found greater loss in glacier thickness by the dGPS method than by using stake measurements of surface mass balance for all three glaciers. This likely resulted from the underlying glacier flow having some effect on glacier thickness, in addition to surface melting. The increase in rates of change in glacier thickness, compared with earlier results, demonstrates either increasing glacier changes in recent years or underestimated results from earlier work.

However, because our primary observation did not cover entire glaciers, and the observation periods remain short, additional future work covering both the accumulation and ablation zones of a single glacier will be necessary to confirm any of our tentative conclusions. Long-term observations, including remote-sensing and ground-based 
observations, will be required to gain a full understanding of glacier thinning, and allow a comprehensive comparison with other approaches. Continuous measurements of glacier thinning provide critical information for estimating the survival of alpine glaciers and for understanding links with climate change. High-precision observations on more glaciers can provide an overall pattern of glacier thinning over the Tibetan Plateau region.

\section{ACKNOWLEDGEMENTS}

We thank two anonymous reviewers, whose constructive comments and detailed suggestions enabled us to revise and improve the paper significantly. William Isherwood editing our writing. This work is funded by the National Basic Research Program of China (2010CB951702), the 'Strategic Priority Research Program (B)' of the Chinese Academy of Sciences (grant No. XDB 03030100) and the National Natural Science Foundation of China (grant No. 41025002, No. 41371086, No. 41101072).

\section{REFERENCES}

Andreassen LM, Paul F, Kääb A and Hausberg JE (2008) Landsatderived glacier inventory for Jotunheimen, Norway, and deduced glacier changes since the 1930s. Cryosphere, 2(2), 131-145 (doi: 10.5194/tc-2-131-2008)

Arcone SA, Lawson DE and Delaney AJ (1995) Short-pulse radar wavelet recovery and resolution of dielectric contrasts within englacial and basal ice of Matanuska Glacier, Alaska, U.S.A. J. Glaciol., 41(137), 68-86

Bhambri R, Bolch T, Chaujar RK and Kulshreshtha SC (2011) Glacier changes in the Garwal Himalaya, India, from 1968 to 2006 based on remote sensing. J. Glaciol., 57(203), 543-556 (doi: 10.3189/002214311796905604)

Bolch T, Menounos B and Wheate R (2010a) Landsat-based inventory of glaciers in western Canada, 1985-2005. Remote Sens. Environ., 114(1), 127-137 (doi: 10.1016/j.rse.2009.08.015)

Bolch T and 7 others (2010b) A glacier inventory for the western Nyainqentanglha Range and Nam Co Basin, Tibet, and glacier changes 1976-2009. Cryosphere, 4(2), 429-467 (doi: 10.5194/ tc-4-419-2010)

Bolch T, Pieczonka T and Benn DI (2011) Multi-decadal mass loss of glaciers in the Everest area (Nepal Himalaya) derived from stereo imagery. Cryosphere, 5(2), 349-358 (doi: 10.5194/tc-5349-2011)

Bolch T and 11 others (2012) The state and fate of Himalayan glaciers. Science, 336(6079), 310-314 (doi: 10.1126/science. 1215828)

Braithwaite RJ (2002) Glacier mass balance: the first 50 years of international monitoring. Progr. Phys. Geogr., 26(1), 76-95 (doi: 10.1191/0309133302pp326ra)

Dyurgerov MB and Meier MF (2000) Twentieth century climate change: evidence from small glaciers. Proc. Natl Acad. Sci. USA (PNAS), 97(4), 1406-1411 (doi: 10.1073/pnas.97.4.1406)

Fujita K and Nuimura T (2011) Spatially heterogeneous wastage of Himalayan glaciers. Proc. Natl Acad. Sci. USA (PNAS), 108(34), 14 011-14 014 (doi: 10.1073/pnas.1106242108)

Gardelle J, Berthier E and Arnaud Y (2012) Slight mass gain of Karakoram glaciers in the early 21 st century. Nature Geosci., 5(5), 322-325 (doi: 10.1038/ngeo1450)

Immerzeel WW, Van Beeke LPH and Bierkens MFP (2010) Climate change will affect the Asian water towers. Science, 328(5984), 1382-1385 (doi: 10.1126/science.1183188)

Jacob T, Wahr J, Pfeffer WT and Swenson S (2012) Recent contributions of glaciers and ice caps to sea level rise. Nature, 482(7386), 514-518 (doi: 10.1038/nature10847)
Kargel JS and 16 others (2005) Multispectral imaging contributions to global land ice measurements from space. Remote Sens. Environ., 99(1-2), 187-219 (doi: 10.1016/j.rse.2005.07.004)

Kaser G, Grosshauser M and Marzeion B (2010) Contribution potential of glaciers to water availability in different climate regimes. Proc. Natl Acad. Sci. USA (PNAS), 107(47), 20 223-20 227 (doi: 10.1073/pnas.1008162107)

Kehrwald NM and 8 others (2008) Mass loss on the Himalayan glaciers endangers water resources. Geophys. Res. Lett., 35(22), L22503 (doi: 10.1029/2008GL035556)

Li J, Liu S, Shangguan D and Zhang Y (2010) Identification of ice elevation change of the Shuiguan River No. 4 glacier in the Qilian Mountains, China. J. Mt Sci. [China], 7(4), 375-379 (doi: 10.1007/s11629-010-1124-1)

Ma L, Tian L, Yang W and Tang W (2008) Measuring the depth of Gurenhekou glacier in the south of the Tibetan plateau using GPR and estimating its volume based on the outcomes. J. Claciol. Geocryol., 30(5), 783-788 [in Chinese with English summary]

Ma L, Tian L, Pu J and Wang P (2010) Recent area and ice volume change of Kangwure Glacier in the middle of Himalayas. Chinese Sci. Bull., 55(20), 2088-2096 (doi: 10.1007/s11434010-3211-7)

Moore JC and 8 others (1999) High-resolution hydrothermal structure of Hansbreen, Spitsbergen, mapped by groundpenetrating radar. J. Glaciol., 45(151), 524-532

Narama C, Kääb A, Duishonakunov $M$ and Abdrakhmatov $K$ (2010) Spatial variability of recent glacier area changes in the Tien Shan Mountains, Central Asia, using Corona ( 1970), Landsat ( 2000), and ALOS ( 2007) satellite data. Global Planet. Change, 71(1-2), 42-54 (doi: 10.1016/j.gloplacha. 2009.08.002)

Nuimura T, Fujita K, Yamaguchi S and Sharma RR (2012) Elevation changes of glaciers revealed by multitemporal digital elevation models calibrated by GPS survey in the Khumbu region, Nepal Himalayas, 1992-2008. J. Glaciol., 58(210), 648-656 (doi: 10.3189/2012JoG11J061)

Pälli A and 6 others (2002) Spatial and temporal variability of snow accumulation using ground-penetrating radar and ice cores on a Svalbard glacier. J. Glaciol., 48(162), 417-424 (doi: 10.3189/ 172756502781831205)

Peduzzi P, Herold C and Silverio W (2010) Assessing high altitude glacier thickness, volume and area changes using field, GIS and remote sensing techniques: the case of Nevado Coropuna (Peru). Cryosphere, 4(3), 313-323 (doi: 10.5194/tc-4-313-2010)

$\mathrm{Pu}$ J, Yao T and Tian L (2006) Change of the Gurenhekou Glacier in Yangbajain Area, Nyainqêntanglha Range. J. Glaciol. Geocryol., 28(6), 861-864 [in Chinese with English summary]

Ren J, Jing Z, Pu J and Qin X (2006) Glacier variations and climate change in the central Himalaya over the past few decades. Ann. Glaciol., 43, 218-222 (doi: 10.3189/172756406781812230)

Scherler D, Bookhagen B and Strecker MR (2011) Spatially variable response of Himalayan glaciers to climate change affected by debris cover. Nature Geosci., 4(3), 156-159 (doi: 10.1038/ ngeo1068)

Shangguan D, Liu S, Ding Y, Zhang Y, Du E and Wu Z (2008) Correspondence. Thinning and retreat of Xiao-Dongkemadi glacier, Tibetan Plateau, since 1993. J. Glaciol., 54(188), 949-951 (doi: 10.3189/002214308787780003)

Shangguan D and 6 others (2010) Changes in the elevation and extent of two glaciers along the Yanglonghe river, Qilian Shan, China. J. Glaciol., 56(196), 309-317 (doi: 10.3189/ 002214310791968566)

Solomon S and 7 others eds. (2007) Climate change 2007: the physical science basis. Contribution of Working Group I to the Fourth Assessment Report of the Intergovernmental Panel on Climate Change. Cambridge University Press, Cambridge

Surazakov AB and Aizen VB (2006) Estimating volume change of mountain glaciers using SRTM and map-based topographic data. IEEE Trans. Geosci. Remote Sens., 44(10), 2991-2995 (doi: 10.1109/TGRS.2006.875357) 
Tian L, Yao T, Wen R, Weng Y, Zhao Z and Qu D (2012) A primary recognition on the climatic significance of ice core isotope record in Naimona'Nyi of West Tibetan Plateau. Quat. Sci., 32(1), 46-52 [in Chinese with English summary]

Watts RD and England AW (1976) Radio-echo sounding of temperate glaciers: ice properties and sounder design criteria. J. Glaciol., 17(75), 39-48

World Glacier Monitoring Service (WGMS) (2008) Global glacier changes: facts and figures, ed. Zemp M, Roer I, Kääb A, Hoelzle M, Paul F and Haeberli W. World Glacier Monitoring Service/ United Nations Environment Programme, Zürich

Yang W and 6 others (2011) Summertime surface energy budget and ablation modeling in the ablation zone of a maritime Tibetan glacier. J. Geophys. Res., 116(D14), D14116 (doi: 10.1029/2010JD015183)

Yao T and 14 others (2012) Different glacier status with atmospheric circulations in Tibetan Plateau and surroundings. Nature Climate Change, 2(7), 663-667 (doi: 10.1038/nclimate1580)
Ye Q, Yao T, Kang S, Chen F and Wang J (2006) Glacier variations in the Naimona'Nyi region, western Himalaya, in the last three decades. Ann. Glaciol., 43, 385-389 (doi: 10.3189/ 172756406781812032)

Ye Q, Zhu L, Zheng H, Naruse R, Zhang X and Kang S (2007) Glacier and lake variations in the Yamzhog Yumco basin, southern Tibetan Plateau, from 1980 to 2000 using remotesensing and GIS technologies. J. Glaciol., 53(183), 673-676 (doi: 10.3189/002214307784409261)

Yu W and 6 others (2013) Different region climate regimes and topography affect the changes in area and mass balance of glaciers on the north and south slopes of the same glacierized massif (the West Nyainqentanglha Range, Tibetan Plateau). J. Hydrol., 495, 64-73 (doi: 10.1016/j.jhydrol.2013.04.034)

Zhang Y, Liu S, Shangguan D and Zhao J (2012) Thinning and shrinkage of Laohugou No. 12 glacier in the Western Qilian Mountains, China, from 1957 to 2007. J. Mt. Sci., 9(3), 343-350 (doi: 10.1007/s11629-009-2296-4)

MS received 23 January 2014 and accepted in revised form 30 June 2014 